\title{
Cortisol influences the ontogeny of both $\alpha$ - and $\beta$-subunits of the cardiac sodium channel in fetal sheep
}

\author{
A I Fahmi ${ }^{1}$, A J Forhead ${ }^{2}$, A L Fowden ${ }^{2}$ and J I Vandenberg ${ }^{1,3}$ \\ ${ }^{1}$ Department of Biochemistry, University of Cambridge, Downing Site, Cambridge CB2 1QW, UK \\ ${ }^{2}$ Department of Physiology, University of Cambridge, Downing Site, Cambridge CB2 3EG, UK \\ ${ }^{3}$ Victor Chang Cardiac Research Institute and Department of Medicine, University of New South Wales, Level 9, 384 Victoria Street, Darlinghurst, NSW2010, \\ Australia \\ (Requests for offprints should be addressed to J Vandenberg, Electrophysiology and Biophysics Unit, Victor Chang Cardiac Research Institute, Level 9, \\ 384 Victoria Street, Darlinghurst, NSW2010, Australia; Email: j.vandenberg@victorchang.unsw.edu.au)
}

\begin{abstract}
During development, the heart has to adapt to changes in shape, size and, at birth, to significant changes in arterial pressure. The orderly contraction of the heart is dependent on the coordinated expression of ion channels at appropriate densities in individual cardiac myocytes. The present study demonstrated that the expression of the $\alpha$-subunit of the cardiac sodium channel, SCN5a, was high at mid gestation but then decreased until 10 days before birth before increasing again. Whereas the $\beta$-subunit, SCN1b, gradually increased in expression towards partum, there was no detectable expression of SCN3b at any gestational time point. Fetal adrenalectomy prior to the normal
\end{abstract}

prepartum surge in cortisol caused a reduction in expression of SCN1b and a 7.0 kb transcript of SCN5a, but not the major $8.5 \mathrm{~kb}$ transcript. Conversely, cortisol infusion into immature fetuses precociously increased expression levels of SCN1b and the SCN5a $7 \cdot 0 \mathrm{~kb}$ transcript. The results show that cortisol regulates cardiac $S C N$ gene expression in fetal sheep during late gestation. These findings could have implications for the aetiology of sudden infant death syndrome and for the intrauterine programming of adult cardiovascular disease.

Journal of Endocrinology (2004) 180, 449-455

\section{Introduction}

In all species studied to date, there are changes in cardiac function at birth that are essential for the transition to extrauterine life (Liggins 1994, Fowden et al. 1998). The heart has to adapt to the increased perfusion of the neonatal lungs and pump against a greater pressure. In many tissues, preparation for the postnatal adaptations vital for neonatal survival has been shown to begin during late gestation and to depend on increased cortisol (glucocorticoid) secretion by the fetal adrenal glands. Furthermore, these changes have been demonstrated in a number of species including rodents, domestic animals, and human and non-human primates (Liggins 1994).

The heart maintains its pumping function through an electrical activity that is governed by the integrated behaviour of a wide range of ion channels expressed in cardiac myocytes. The voltage-gated sodium channels are critical elements of action potential initiation and propagation in excitable cells. They are multimeric structures composed of a pore-forming $\alpha$-subunit and smaller auxiliary subunits embedded in the plasma membrane. The pore-forming subunits of cardiac sodium channels are encoded by SCN5a. Three sodium channel auxiliary subunit genes have been defined thus far: $S C N 1 b$ (encodes $\beta 1$ and $\beta 1 \mathrm{~A}$ ), SCN2b (encodes $\beta 2$ ) and $S C N 3 b$ (encodes $\beta 3$ ) (Catterall 2000). Both SCN1b and SCN3b $\beta$-subunits are expressed in cardiac tissue from a range of species (including rodents, humans and sheep) and are known to modulate the kinetics of the cardiac sodium channel $\alpha$-subunit (Nuss et al. 1995, Qu et al. 1995, Dhar Malhotra et al. 2001, Fahmi et al. 2001). Nevertheless, the role of $\beta$-subunits in the heart is incompletely understood, in particular there is very little known about what regulates the expression of sodium channel subunits in the heart.

Recent reports in man have linked mutations in SCN5a with sudden infant death syndrome (SIDS) (Schwartz et al. 2000, Ackerman et al. 2001, Wedekind et al. 2001). The peak incidence of SIDS is between 2 and 4 months, which corresponds to the period when the normal circadian rhythm in cortisol levels is being established in the human infant (Gordon et al. 1999). Further, cohort analysis using data from the 1987 United States Birth Cohort Linked Birth/Infant Death implied that preterm human infants are at higher risks of SIDS than term infants (Malloy \& Hoffman 1995), thus raising the possibility that abnormalities in SCN expression linked to dysregulation of 
cortisol metabolism may contribute to the cause of death in SIDS in human infants.

The aims of this study therefore were to investigate the patterns of expression of SCN5a, SCN1b and SCN3b in the fetal sheep heart during development and to examine the role of cortisol in regulating developmental changes in sodium channel subunit expression.

\section{Materials and Methods}

\section{Animals}

A total of 30 Welsh Mountain sheep fetuses of known gestational age were used in this study together with two additional newborn lambs and three adult pregnant ewes. The ewes were housed in individual cages and fed with concentrate (200 g/day: H.G. Beart, Stonebridge, Kings Lynn, UK) and hay and allowed to feed ad libitum. Food but not water was withheld for 18-24 h before surgery. Normal feeding patterns were restored within $24 \mathrm{~h}$ of operation. All experimental procedures were carried out in accordance with the UK Animals (Scientific Procedures) Act 1986.

\section{Surgical and experimental procedures}

Under halothane anaesthesia $\left(1.5 \%\right.$ in $\left.\mathrm{O}_{2} / \mathrm{N}_{2} \mathrm{O}\right)$ one of the following procedures was carried out between 115 and 118 days of gestation (term $=143 \pm 2$ days) using previously published surgical methods ( $\mathrm{Li}$ et al. 1996): (a) vascular catheterization of intact control fetuses $(n=12)$ or (b) bilateral adrenalectomy of the fetus $(n=5)$. At least 6 days after catheterization, the intact fetuses were infused intravenously with either cortisol $(1-3 \mathrm{mg} /$ day in $3 \mathrm{ml}$ $0.9 \%$ (wt/vol) saline, EF-Cortelan, Glaxo Ltd, Greenford, Middlesex, UK, $n=6)$ or saline $(0.9 \% \mathrm{wt} / \mathrm{vol}$ at $3 \mathrm{ml} /$ day, $n=6)$ for 5 days before delivery for tissue collection at 125-130 days of gestation. The dose of cortisol was chosen to provide a progressive rise in the fetal plasma cortisol concentration that mimicked the normal prepartum cortisol surge (Fowden et al. 1996).

\section{Ovine tissue collection}

All infused $(n=12)$, adrenalectomized fetuses $(n=5$ at 139-144 days) and 13 additional untreated intact fetuses (104-145 days) were delivered by Caesarean section under sodium pentobarbitone anaesthesia $(20 \mathrm{mg} / \mathrm{kg}$ i.v.). Cord blood samples were taken from the majority of fetuses by venepuncture from the umbilical artery after anaesthesia had been induced. After administration of a lethal dose of sodium pentobarbitone $(200 \mathrm{mg} / \mathrm{kg}), 3-5 \mathrm{~g}$ samples of the ventricle tips of the fetal heart were collected and immediately frozen in liquid nitrogen and stored at $-80^{\circ} \mathrm{C}$. A range of other tissues was also collected as part of another study. All blood samples were centrifuged
Table 1 PCR primers used for synthesis of cDNA probes for Northern blotting

$\begin{array}{lll}\text { SCN5a } & \text { F } & \text { CCT CGA CCC CTA CTA CTA CTT CC } \\ \text { (exon 15-16) } & \text { R } & \text { GAA GAG ATT CAG GAC CAA AGG } \\ \text { SCN5a } & \text { F } & \text { GGC TGT GTC CGG CGC TGT CC } \\ \text { (exon 20/21) } & \text { R } & \text { TTG AGC AGC ATC TCC AGC AC } \\ \text { SCN1b } & \text { F } & \text { GAT CCT GCG CAA TGG CAG CCG G } \\ & \text { R } & \text { CGA TGG ATG CCA TGT CTC TGT TG } \\ \text { SCN3b } & \text { F } & \text { GTG TGT GTG GAA GTG CCC TCG GAG } \\ & \text { R } & \text { GAC CAC GGA GGT GAA GTC TTC TCC } \\ \text { GAPDH } & \text { F } & \text { GAC TCA TGA CCA CAG TCC ATG C } \\ & \text { R } & \text { CCT GTT GCT GTA GCC AAA TTC G }\end{array}$

$F$, forward; R, reverse.

immediately at $4{ }^{\circ} \mathrm{C}$ and the plasma stored at $-20{ }^{\circ} \mathrm{C}$ until analysis for plasma cortisol. Plasma cortisol concentrations were measured by radioimmunoassay validated for use with ovine plasma (Robinson et al. 1983). At delivery, no obvious adrenal remnants were found in any adrenalectomized fetuses.

\section{Molecular analyses}

Northern and Western blot analyses were performed on the tissue within 6 months of collection as described previously (Fahmi et al. 2001). Sheep cDNA probes (see Table 1 for the list of forward and reverse primers used for cDNA synthesis) for SCN5a, SCN1b, SCN3b and glyceraldehyde-3-phosphate dehydrogenase (GAPDH) were labelled with ${ }^{32} \mathrm{P}-\mathrm{CTP}$ using the multiprime labelling kit (Amersham). Membrane proteins were extracted from three fetal sheep hearts for each gestational period tested. Proteins levels were quantified using standard Bradford assay (BioRad, UK) and $60 \mu \mathrm{g}$ of protein were separated on a 3-8\% Tris-glycine SDSpolyacrylamide gels and transferred to polyvinylidene difluoride membranes. The SCN1b rabbit polyclonal antibody (a kind gift from Lori Isom, University of Michigan, MI, USA) was raised against the peptide sequence corresponding to the initial 18 amino acids of rat $\beta 1$ sequence, GGCVEVDSETEAVYGMTF (Isom et al. 1992). The SCN3b rabbit polyclonal antibody was raised against the peptide FEFEAHRPFVKTTRC, corresponding to residues 126-140 of the rat SCN3b sequence (Fahmi et al. 2001). The pan-specific sodium channel antibody, SP19 (Alomone Labs, Jerusalem, Israel) was raised in rabbit against highly purified peptide TEEQKKYYNAMKKLGSKK(C), corresponding to residues $1491-1508$ of the $\alpha$-subunit of rat type I voltage gate sodium channel.

Data analysis

Autoradiograms were scanned (256 greyscales) using a UMAX Powerlook III scanner and the optical density 
Fetuses

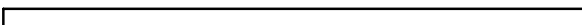

104

128

131

137139

\section{SCN5a}

SCN1b

$\mathrm{SCN} 3 \mathrm{~b}$

GAPDH

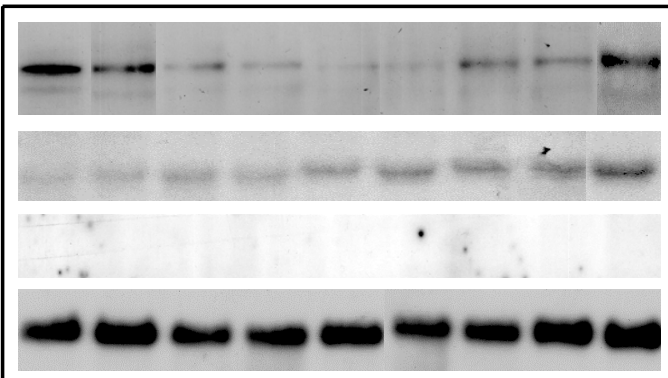

Adult



LA LV

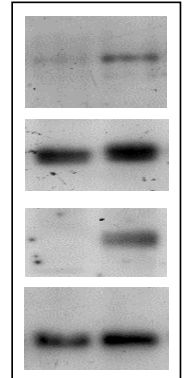

Figure 1 Ontogeny of sodium channel subunit mRNA expression. A Northern blot is shown containing total RNA $(15 \mu \mathrm{g})$ prepared from sheep fetuses at 104, 113, 126, 128, $131,137,139$ and 141 days of gestation and newborn lambs (NB) probed successively with ${ }^{32}$ P-labelled cDNA for sheep SCN5a $(\sim 8.5 \mathrm{~kb}), \operatorname{SCN} 1 \mathrm{~b}(\sim 1.5 \mathrm{~kb}), \operatorname{SCN} 3 \mathrm{~b}(\sim 5.0 \mathrm{~kb})$ and GAPDH $(1.0 \mathrm{~kb})$. Total RNA from adult left atrium (LA) and left ventricle (LV) were run as positive controls (right panel).

(OD) for each autoradiograph was calibrated using a photographic step tablet (Eastman Kodak Company, Rochester, NY, USA). All results are reported as means \pm S.E.M. Statistical significance was assessed by ANOVA, Student-Newman-Keuls $t$-tests, or linear regressions using Statview v5 $\cdot 0 \cdot 1$. (SAS Institute, Inc., Cary, NC, USA). A $P$ value of $<0 \cdot 05$ was regarded as significant.

\section{Results}

\section{Developmental changes}

Typical examples of Northern blots illustrating the developmental changes in sodium channel subunit mRNA expression in sheep heart are shown in Fig. 1. There is a relatively high level of expression of SCN5a at 104-113 days of gestation, which then declined between 126 and 137 days of gestation before increasing again during late gestation (139-141 days). The SCN1b transcript was barely detectable at 104-113 days of gestation but thereafter there was a steady increase in the level of expression (Fig. 1). The rise in SCN1b expression close to term closely parallelled the normal prepartum rise in fetal plasma cortisol (Table 2). The SCN3b transcript was undetectable in hearts prior to birth (Fig. 1), although it was clearly seen in the left ventricle samples from adult animals (Fig. 1, right panel).

Typical examples of Western blots incubated with SP19 and SCN1b antibodies are illustrated in Fig. 2. SP19 detected two bands in the region $230-250 \mathrm{kDa}$. The higher molecular weight band detected by SP19 was not present when samples were treated with $\mathrm{N}$-glycosidase F. Therefore the two bands are likely to represent glycosylated and non-glycosylated forms of SCN5a (Fahmi 2001). The level of $\alpha$-subunit expression was high from 104 to 113 days of gestation (OD: $0 \cdot 42 \pm 0 \cdot 12, n=3$ ), decreased at 128-139 days (OD: $0 \cdot 18 \pm 0 \cdot 13, n=3$; $P<0.05$ compared with both early and late gestation) before increasing again at 141 days and in newborn (OD: $0 \cdot 45 \pm 0 \cdot 13, n=3)$. The SCN1b antibody detected a major band at about $50 \mathrm{kDa}$, the level of which was uniform

Table 2 Plasma cortisol levels and changes in relative abundances of SCN5a and SCN1b mRNA during development in fetal sheep. $n=3$ at each gestational age range

\begin{tabular}{|c|c|c|c|c|}
\hline & \multicolumn{4}{|c|}{ Gestational age (days) } \\
\hline & $110-113$ & $127-132$ & $137-141$ & 143 to $N B$ \\
\hline Cortisol (ng/ml) & $7 \cdot 7 \pm 2 \cdot 3^{\mathrm{a}}$ & $10 \cdot 9 \pm 2 \cdot 1^{\mathrm{a}}$ & $33 \cdot 8 \pm 6 \cdot 8^{b}$ & $54 \cdot 8 \pm 12 \cdot 8^{\mathrm{C}}$ \\
\hline SCN5a (OD) & $0 \cdot 31 \pm 0 \cdot 08^{a}$ & $0 \cdot 14 \pm 0 \cdot 04^{b}$ & $0 \cdot 30 \pm 0 \cdot 10^{\mathrm{a}}$ & $0 \cdot 45 \pm 0 \cdot 12^{a}$ \\
\hline SCN1b (OD) & $0 \cdot 035 \pm 0 \cdot 01^{a}$ & $0 \cdot 071 \pm 0.01^{\mathrm{b}}$ & $0 \cdot 15 \pm 0 \cdot 04^{\mathrm{c}}$ & $0 \cdot 18 \pm 0 \cdot 05^{\mathrm{c}}$ \\
\hline
\end{tabular}

Values within each row with different superscripts are significantly different from each other (ANOVA, $P<0 \cdot 05)$. OD, optical density; NB, newborn. 


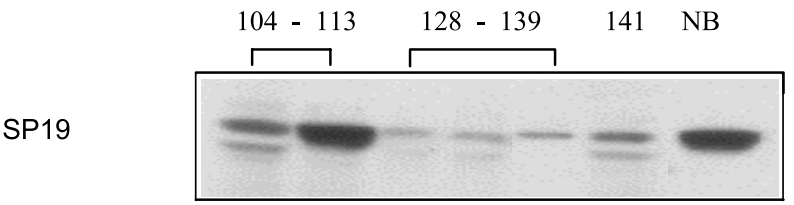

SCN1b

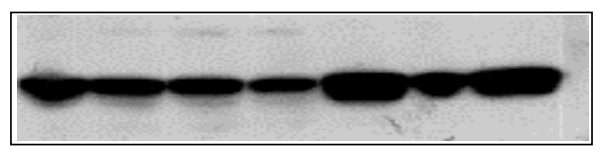

Figure 2 Ontogeny of sodium channel subunit protein expression. A Western blot is shown containing total protein $(60 \mu \mathrm{g})$ prepared from fetuses at 104-113 days of gestation, 128-139 days of gestation and late gestation (141 days to newborn (NB)) and incubated with sodium channel $\alpha$-subunits antibody, SP19 ( 220-270 kDa) (see Materials and Methods) and $\beta 1$-subunit, SCN1b ( $50 \mathrm{kDa})$ (see Isom et al. 1992).

throughout gestation (OD at 104-113 days of gestation $0 \cdot 68 \pm 0 \cdot 09, n=3$; at $128-139$ days of gestation $0.66 \pm$ $0 \cdot 11, n=3$; and in day 141 and newborn $0 \cdot 69 \pm 0 \cdot 11$, $n=3$ ). A minor band at $>50 \mathrm{kDa}$ was also detected in newborn sheep and late gestation fetal hearts. SCN3b antibody did not detect any protein at any of the gestational ages examined (data not shown).

\section{The effect of manipulating the cortisol level}

To determine whether changes in sodium channel subunit expression during development were related to changes in plasma cortisol levels, sodium channel mRNA and protein expression were measured in hearts taken from fetuses near term, in which the prepartum rise in plasma cortisol had been prevented by adrenalectomy and from 125-130 days of gestation fetuses that had been infused with cortisol for 5 days before delivery to mimic the prepartum cortisol surge (Table 3).

Typical examples of Northern and Western blots performed on tissues following alteration of cortisol levels are illustrated in Fig. 3 and the results are summarized in
Table 3. Increases in the fetal cortisol level had little effect on the level of expression of the $8.5 \mathrm{~kb}$ SCN5a transcript (Fig. 3A,B). However, expression of a $7 \cdot 0 \mathrm{~kb}$ SCN5a transcript (see below) was affected by changes in the fetal cortisol level (Fig. 3A,B). An increase in fetal cortisol concentration, either endogenously or by exogenous infusion, was associated with a significant increase in expression of the $7 \cdot 0 \mathrm{~kb}$ transcript (see Table 3). Conversely, when the normal prepartum rise in cortisol was prevented by fetal adrenalectomy, the increase in expression of the $7 \cdot 0 \mathrm{~kb}$ transcript was prevented (see Fig. $3 \mathrm{~B}$ and Table 3 ). Western blots using SP19 showed no significant effect of cortisol on levels of sodium channel protein (Fig. 3C).

Expression of both SCN1b mRNA and protein were affected by the fetal cortisol level. Cortisol infusion increased SCN1b mRNA and protein expression in fetal hearts at 125-130 days (Fig. 3A,C) while adrenalectomy prevented the normal increase in SCN1b mRNA and protein levels observed in late gestation (Fig. 3B,D, Table 3). Furthermore, there was a significant correlation between the level of SCN1b mRNA and plasma cortisol levels (see Fig. 4).

\section{Discussion}

\section{Sodium channel subunit expression during heart development}

The present study demonstrates that there is a heterogeneous expression of the sodium channel, SCN5a and its auxiliary $\beta$-subunits during heart development in sheep. SCN5a mRNA and protein expression are high at $70 \%$ gestation ( $\sim 110$ days of gestation), before declining and then rising again 10-15 days prepartum (see Fig. 1). Expression levels of SCN1b mRNA relative to GAPDH mRNA were low at 104-113 days of gestation and increased gradually until birth. On the other hand, SCN3b mRNA and protein were not detected at any stage of heart development, although it was highly expressed in sheep adult left ventricle (see Fig. 1).

The increase in SCN1b mRNA and immunoreactive protein during late gestation would be expected to lead to

Table 3 Plasma cortisol levels and changes in relative abundances of SCN5a and SCN1b mRNA in fetal sheep following manipulation of cortisol levels. $n=3$ at each gestational age range

\begin{tabular}{|c|c|c|c|c|}
\hline & \multicolumn{4}{|l|}{ Gestational age } \\
\hline & \multicolumn{2}{|l|}{ 125-130 days } & \multicolumn{2}{|l|}{ 143-145 days } \\
\hline & Saline & Cortisol & Control & Adrenalectomized \\
\hline \multicolumn{5}{|l|}{ Treatment } \\
\hline Cortisol (ng/ml) & $10 \cdot 9 \pm 2 \cdot 1^{\mathrm{a}}$ & $52 \cdot 3 \pm 7 \cdot 2^{b}$ & $32 \cdot 5 \pm 4 \cdot 6^{\mathrm{a}}$ & $7 \cdot 4 \pm 0 \cdot 5^{c}$ \\
\hline SCN5a (OD), $8.5 \mathrm{~kb}$ & $0 \cdot 123 \pm 0 \cdot 04$ & $0 \cdot 12 \pm 0 \cdot 04$ & $0 \cdot 30 \pm 0 \cdot 05$ & $0 \cdot 30 \pm 0 \cdot 05$ \\
\hline SCN5a (OD), $7 \cdot 0 \mathrm{~kb}$ & $0 \cdot 05 \pm 0.001^{\mathrm{a}}$ & $0 \cdot 131 \pm 0 \cdot 04^{b}$ & $0 \cdot 27 \pm 0 \cdot 04^{\mathrm{a}}$ & $0.05 \pm 0.001^{a}$ \\
\hline SCN1b (OD) & $0.08 \pm 0.001^{\mathrm{a}}$ & $0 \cdot 187 \pm 0.03^{b}$ & $0 \cdot 19 \pm 0 \cdot 04^{\mathrm{a}}$ & $0 \cdot 10 \pm 0 \cdot 04^{\mathrm{b}}$ \\
\hline
\end{tabular}

Values with different superscripts within each row for each group (i.e. 125-130 or 143-145 days of gestation) are significantly different from each other (ANOVA, $P<0 \cdot 05$ ). 
A)

$125-130$

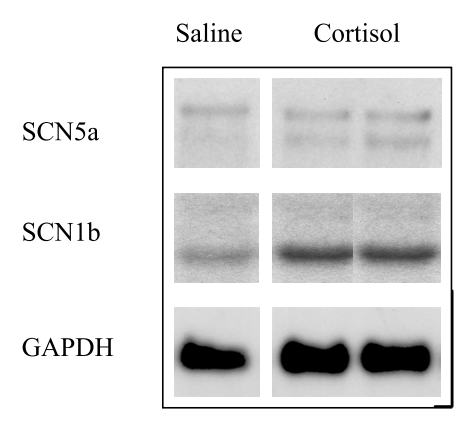

C)

$125-130$

Saline Cortisol

SP19

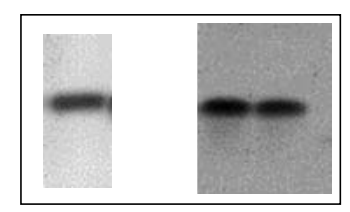

SCN1b

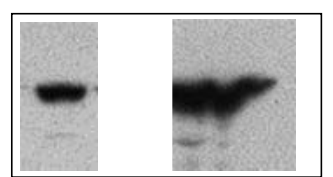

B)

$139-144$

Control ADX

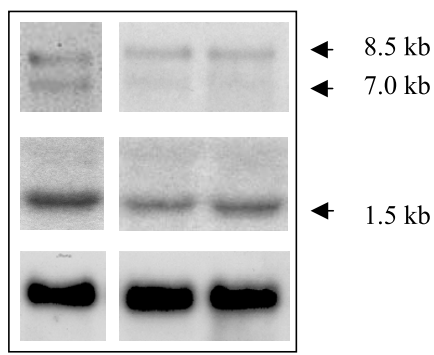

D)

$139-144$

Control ADX
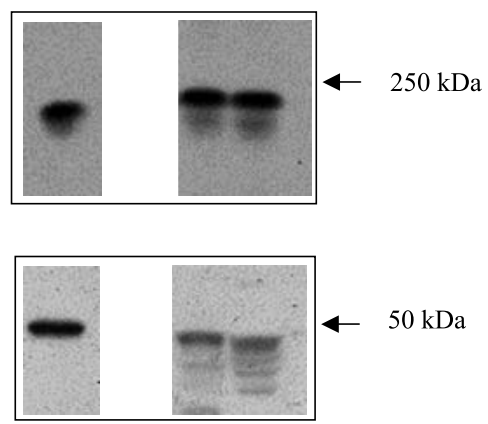

Figure 3 Analyses of effect of fetal adrenalectomy and cortisol infusion on expression of SCN5a and SCN1b. (A, B) Northern blots containing total RNA (15 $\mu \mathrm{g})$ prepared from: (A) hearts of fetuses delivered at 125-130 days of gestation \pm cortisol infusion probed with

${ }^{32}$ P-labelled cDNA for sheep SCN5a, SCN1b and GAPDH; and (B) hearts of fetuses delivered at 139-144 days of gestation that had or had not been adrenalectomized (ADX) at 115-118 days of gestation. (C, D) Western blots containing total protein (60 $\mu \mathrm{g})$ prepared from: (C) hearts of fetuses delivered at 125-130 days of gestation \pm cortisol infusion incubated with SP19 and SCN1b antibodies; and (D) hearts of fetuses delivered at 139-144 days of gestation that had or had not been adrenalectomized at 115-118 days of gestation. Duplicate blots represent samples from different animals.

an increase in the density of functional sodium channels (Fahmi et al. 2001). Therefore, the changes in sodium channel expression reported here are consistent with the ontogenesis of the electrical properties of myocardial cells during development in mice, guinea pigs and chick embryos (Renaud et al. 1981, Davies et al. 1996, Kato et al. 1996). At the early stages of embryonic development the maximal upstroke velocity $\left(V_{\max }\right)$ of the action potential is clearly sodium channel dependent, although it is significantly slower than in adults $\left(V_{\max }<10 \mathrm{~V} / \mathrm{s}\right.$ in embryos compared with $\sim 100 \mathrm{~V} / \mathrm{s}$ in neonates and adults) (Renaud et al. 1981). Further, sodium current amplitude is low in myocytes isolated from murine hearts at mid gestation $(\sim 10 \mathrm{pA} / \mathrm{pF})$, but increases by birth in mice to $\sim 100 \mathrm{pA} / \mathrm{pF}$ (Davies et al. 1996). Similarly, in myocytes from guinea pigs, there is a shortening of the action potential during the period of late gestation during which fetal cortisol concentrations rise (Kato et al. 1996, Fowden et al. 1998). The significant level of SCN5a expression in ovine hearts at mid gestation in the current study is also consistent with the recent finding that mice with homozygous SCN5a knockout die during mid gestation (approx. day 10.5) (Papadatos et al. 2002).

The changes in sodium channel subunit density levels during development are also likely to contribute to the slower conduction in fetal compared with adult hearts. The expression of gap junctional proteins in cardiac cells will also influence conduction velocity during fetal development. Connexins 40 and 43 mRNA levels are low at early gestation and then increase towards term in rat and mouse (Fishman et al. 1991, Delorme et al. 1997). It is therefore likely that increases in conduction velocity are a reflection of changes in both sodium channel density and gap junction density. 


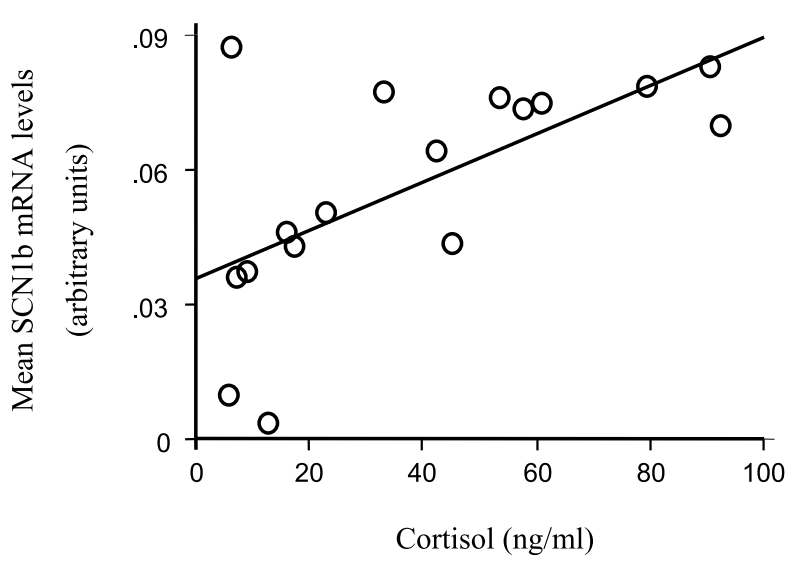

Figure 4 Correlation of SCN1b transcript and cortisol levels. The correlation between plasma cortisol levels and level of SCN1b mRNA expression was statistically significant $\left(r^{2}=0 \cdot 41, P<0 \cdot 05\right)$.

\section{Effect of cortisol on expression levels of sodium channel}

One of the key changes that govern maturation of the fetal tissues is the prepartum surge in hormone release, particularly cortisol secretion by the fetal adrenal glands (Liggins 1994). Cortisol has been implicated in the developmental regulation of many ion channels. For example, dexamethasone, a glucocorticoid receptor agonist, upregulates the expression of $\mathrm{Kv} 1.5$ potassium channel mRNA and immunoreactive protein in rat ventricles (Takimoto \& Levitan 1994). Cortisol also mediates the developmental changes in expression of ion channels and transporters in other tissues including, for example, the rise in both $\mathrm{Na}^{+} / \mathrm{K}^{+}$-ATPase mRNA abundance (Celsi et al. 1993) and the $\mathrm{Na}^{+}-\mathrm{H}^{+}$exchanger activity and mRNA levels (Guillery et al. 1995) in the fetal ovine kidney.

The present results demonstrate that cortisol specifically upregulates the expression of SCN1b (see Figs 1 and 4) and the $7.0 \mathrm{~kb}$ transcript of SCN5a, but not the $8.5 \mathrm{~kb}$ transcript of SCN5a in fetal ovine heart in vivo. Expression of SCN1b and the $7 \cdot 0 \mathrm{~kb}$ transcript of SCN5a increased towards term in parallel with the prepartum cortisol surge in the fetus. When this increase in cortisol was prevented by fetal adrenalectomy, the prepartum increases in SCN1b and SCN5a $(7 \cdot 0 \mathrm{~kb}$ transcript) were abolished, whilst levels of SCN5a ( $8.5 \mathrm{~kb}$ transcript) were similar to those observed in intact fetuses close to term (see Fig. 3). Administration of physiological doses of cortisol to intact fetuses at times in mid gestation (125-130 days) also increased the levels of SCN1b and SCN5a $(7 \cdot 0 \mathrm{~kb}$ transcript) to values similar to those observed in older fetuses with high endogenous cortisol concentrations (Derks et al. 1997, Fowden et al. 1998). SCN5a (8.5 kb transcript) levels did not increase as a result of cortisol infusion. The simplest explanation for the results observed in this study is a direct effect of cortisol, acting via glucocorticoid response elements, GREs (Rousseau 1984). Several of the genes known to be regulated by cortisol (e.g. insulin-like growth factor-II (IGF-II) and erythropoietin) have GREs in their promoter regions to allow direct transcriptional control of the gene by cortisol in fetal sheep (Li et al. 1996, Lim et al. 1996). However, other genes that are apparently glucocorticoid sensitive do not appear to have recognizable GRE consensus sequences (Dickson et al. 1991). Alternatively, cortisol may act indirectly through other hormones such as insulin-like growth factor-I (IGF-I) and triiodothyronine $\left(\mathrm{T}_{3}\right)$, and/or enzymes, such as the SGK1 kinase, which are glucocorticoid inducible and known to affect cardiac function postnatally (Li et al. 1996, Wickenden et al. 1997, Boehmer et al. 2003). Clearly, further studies are required to determine the mechanism by which cortisol acts on the various promoters of the SCN1b and SCN5a genes.

In summary, the current results demonstrate that cortisol has a physiological role in regulating the cardiac SCN channel and its subunits during ovine development. Abnormalities in SCN gene expression may, therefore, occur in infants delivered prematurely before the prepartum cortisol surge. Similarly, early exposure to cortisol during adverse intrauterine conditions may lead to inappropriate changes in SCN gene expression with long-term consequences for cardiac function, both before and after birth. These findings, therefore, have important implications both for the aetiology of SIDS and for the intrauterine programming of adult cardiovascular disease (Barker 2002).

\section{Funding}

J I V was supported by a British Heart Foundation Basic Sciences Award (BS 95/002). We also gratefully acknowledge project grant support from the British Heart Foundation (PG 98/164 to J I V) and the Biotechnology and Biological Sciences Research Council (to A L F and A J F).

\section{References}

Ackerman MJ, Siu BL, Sturner WQ, Tester DJ, Valdivia CR, Makielski JC \& Towbin JA 2001 Postmortem molecular analysis of SCN5A defects in sudden infant death syndrome. Journal of the American Medical Association 286 2264-2269.

Barker D 2002 Fetal programming of coronary heart disease. Trends in Endocrinology and Metabolism 13 364-368.

Boehmer C, Wilhelm V, Palmada M, Wallisch S, Henke G, Brinkmeier H, Cohen P, Pieske B \& Lang F 2003 Serum and glucocorticoid inducible kinases in the regulation of the cardiac sodium channel SCN5A. Cardiovascular Research 57 1079-1084.

Catterall WA 2000 From ionic currents to molecular mechanisms: the structure and function of voltage-gated sodium channels. Neuron 26 $13-25$.

Celsi G, Wang ZM, Akusjarvi G \& Aperia A 1993 Sensitive periods for glucocorticoids' regulation of $\mathrm{Na}+, \mathrm{K}(+)$-ATPase mRNA in the developing lung and kidney. Pediatric Research 33 5-9.

Davies MP, An RH, Doevendans P, Kubalak S, Chien KR \& Kass RS 1996 Developmental changes in ionic channel activity in the embryonic murine heart. Circulation Research 78 15-25. 
Delorme B, Dahl E, Jarry-Guichard T, Briand JP, Willecke K, Gros D \& Theveniau-Ruissy M 1997 Expression pattern of connexin gene products at the early developmental stages of the mouse cardiovascular system. Circulation Research 81 423-437.

Derks JB, Giussani DA, Jenkins SL, Wentworth RA, Visser GH, Padbury JF \& Nathanielsz PW 1997 A comparative study of cardiovascular, endocrine and behavioural effects of betamethasone and dexamethasone administration to fetal sheep. Journal of Physiology 499 217-226.

Dhar Malhotra J, Chen C, Rivolta I, Abriel H, Malhotra R, Mattei LN, Brosius FC, Kass RS \& Isom LL 2001 Characterization of sodium channel alpha- and beta-subunits in rat and mouse cardiac myocytes. Circulation 103 1303-1310.

Dickson MC, Saunders JC \& Gilmour RS 1991 The ovine insulin-like growth factor-I gene: characterization, expression and identification of a putative promoter. Journal of Molecular Endocrinology 6 17-31.

Fahmi AI 2001 Molecular characterisation of the cardiac sodium channel subunits. Cambridge: University of Cambridge.

Fahmi AI, Patel M, Stevens EB, Fowden AL, John JE, 3rd, Lee K, Pinnock R, Morgan K, Jackson AP \& Vandenberg JI 2001 The sodium channel beta-subunit SCN3b modulates the kinetics of SCN5a and is expressed heterogeneously in sheep heart. Journal of Physiology 537 693-700.

Fishman GI, Moreno AP, Spray DC \& Leinwand LA 1991 Functional analysis of human cardiac gap junction channel mutants. PNAS $\mathbf{8 8}$ $3525-3529$.

Fowden AL, Szemere J, Hughes P, Gilmour RS \& Forhead AJ 1996 The effects of cortisol on the growth rate of the sheep fetus during late gestation. Journal of Endocrinology 151 97-105.

Fowden AL, Li J \& Forhead AJ 1998 Glucocorticoids and the preparation for life after birth: are there long-term consequences of the life insurance? Proceedings of the Nutrition Society 57 113-122.

Gordon AE, Al Madani O, Weir DM, Busuttil A \& Blackwell C 1999 Cortisol levels and control of inflammatory responses to toxic shock syndrome toxin-1 (TSST-1): the prevalence of night-time deaths in sudden infant death syndrome (SIDS). FEMS Immunology and Medical Microbiology 25 199-206.

Guillery EN, Karniski LP, Mathews MS, Page WV, Orlowski J, Jose PA \& Robillard JE 1995 Role of glucocorticoids in the maturation of renal cortical $\mathrm{Na}+/ \mathrm{H}+$ exchanger activity during fetal life in sheep. American Journal of Physiology 268 F710-F717.

Isom LL, De Jongh KS, Patton DE, Reber BF, Offord J, Charbonneau H, Walsh K, Goldin AL \& Catterall WA 1992 Primary structure and functional expression of the beta 1 subunit of the rat brain sodium channel. Science 256 839-842.

Kato Y, Masumiya H, Agata N, Tanaka H \& Shigenoubu K 1996 Developmental changes in action potential and membrane currents in fetal, neonatal and adult guinea pig ventricular myocytes. Journal of Molecular and Cellular Cardiology 28 1515-1522.

Li J, Owens JA, Owens PC, Saunders JC, Fowden AL \& Gilmour RS 1996 The ontogeny of hepatic growth hormone receptor and insulin-like growth factor I gene expression in the sheep fetus during late gestation: developmental regulation by cortisol. Endocrinology 137 1650-1657.

Liggins GC 1994 The role of cortisol in preparing the fetus for birth. Reproduction, Fertility and Development 6 141-150.

Lim GB, Dodic M, Earnest L, Jeyaseelan K \& Wintour EM 1996 Regulation of erythropoietin gene expression in fetal sheep by glucocorticoids. Endocrinology 137 1658-1663.

Malloy MH \& Hoffman HJ 1995 Prematurity, sudden infant death syndrome and age of death. Pediatrics 96 464-471.

Nuss HB, Chiamvimonvat N, Perez-Garcia MT, Tomaselli GF \& Marban E 1995 Functional association of the beta 1 subunit with human cardiac (hH1) and rat skeletal muscle (mu 1) sodium channel alpha subunits expressed in Xenopus oocytes. Journal of General Physiology 106 1171-1191.

Papadatos GAW, Wallerstein PMR, Head CEG, Ratcliff R, Brady PA, Benndorf K, Saumarez RC, Trezise AEO, Huang CL-H, Vandenberg JI, Colledge WH \& Grace AA 2002 Slowed conduction and ventricular tachycardia after targeted disruption of the cardiac sodium channel Scn5a. PNAS 99 6210-6215.

$\mathrm{Qu}$ Y, Isom LL, Westenbroek RE, Rogers JC, Tanada TN, McCormick KA, Scheuer T \& Catterall WA 1995 Modulation of cardiac $\mathrm{Na}^{+}$channel expression in Xenopus oocytes by beta 1 subunits. Journal of Biological Chemistry 270 25696-25701.

Renaud JF, Romey G, Lombet A \& Lazdunski M 1981 Differentiation of the fast $\mathrm{Na}^{+}$channel in embryonic heart cells: interaction of the channel with neurotoxins. PNAS 78 5348-5352.

Robinson PM, Comline RS, Fowden AL \& Silver M 1983 Adrenal cortex of fetal lamb: changes after hypophysectomy and effects of Synacthen on cytoarchitecture and secretory activity. Quarterly Journal of Experimental Physiology 68 15-27.

Rousseau GG 1984 Control of gene expression by glucocorticoid hormones. Biochemical Journal 224 1-12.

Schwartz PJ, Priori SG, Dumaine R, Napolitano C, Antzelevitch C, Stramba-Badiale M, Richard TA, Berti MR \& Bloise R 2000 A molecular link between the sudden infant death syndrome and the long-QT syndrome. New England Journal of Medicine 343 262-267.

Takimoto K \& Levitan ES 1994 Glucocorticoid induction of Kv1.5 $\mathrm{K}^{+}$channel gene expression in ventricle of rat heart. Circulation Research 75 1006-1013.

Wedekind H, Smits JP, Schulze-Bahr E, Arnold R, Veldkamp MW, Bajanowski T, Borggrefe M, Brinkmann B, Warnecke I, Funke H, Bhuiyan ZA, Wilde AA, Breithardt G \& Haverkamp W 2001 De novo mutation in the SCN5A gene associated with early onset of sudden infant death. Circulation 104 1158-1164.

Wickenden AD, Kaprielian R, Parker TG, Jones OT \& Backx PH 1997 Effects of development and thyroid hormone on $\mathrm{K}^{+}$currents and $\mathrm{K}^{+}$channel gene expression in rat ventricle. Journal of Physiology 504 271-286.

Received 19 September 2003 Accepted 27 November 2003 